Journal of Social Sciences (COES\&RJ-JSS)

ISSN (E): 2305-9249 ISSN (P): 2305-9494

Publisher: Centre of Excellence for Scientific \& Research Journalism, COES\&RJ LLC

Online Publication Date: $1^{\text {st }}$ July 2017

Online Issue: Volume 6, Number 3, July 2017

https://doi.org/10.25255/jss.2017.6.3.518.531

\title{
Impact of Apiculture on the Household Income of Rural Poor in Mountains of Chitral District in Pakistan
}

\author{
Tariq Ahmad* \\ Ghulam-Muhammad Shah*(Corresponding author) \\ Farid Ahmad* \\ Uma Partap* \\ Sajjad Ahmad** \\ *International Center for Integrated Mountain Development (ICIMOD). \\ ** Aga Khan Rural Support Programme (AKRSP), Regional Office, Chitral
}

\begin{abstract}
Livelihoods of communities living in mountain areas is typically dependent on subsistence agriculture and smallholder farming. The needs of smallholder rural mountain farmers for livelihoods cannot be addressed without providing them alternative income within available resources. Beekeeping has proven to be such an alternative livelihood option with potential of providing alternative income security to smallholder farmers living in rural mountain areas.However, how successful and sustainable beekeeping interventions are in terms of presenting a reliable alternative livelihood option particularly in rural mountain context of Pakistan is less explored. In this context, an impact assessment approach has been used in an ex-post scenario to better understand impacts attributable to an intervention.Applying such approaches in ex-post scenarios help better understand relevance, effectiveness, and suitability and sustainability aspects of interventions. This paper assesses impact of beekeeping pilot intervention on the household income of rural poor living in mountain areas of Pakistan and looks into suitability and sustainability aspects of the intervention in the ex-post scenario. Using 'Difference-in-Difference' approach, impact and sustainability of pilot intervention was assessed 4 years after conclusionof the intervention. Findings of the study suggest that average income of beneficiary households from beekeeping is increased by $51.54 \%$ compared to the average income of beneficiary households assessed at the end of the pilot intervention. Study concludes that interventions on strengthening alternative income security optionsin rural mountain context are sustainable given that the alternative livelihood options are carefully identified and implemented in a participatory manner.
\end{abstract}

Keywords: Pilot intervention, alternative income, alternative livelihoods, impact assessment, ex-post scenario, difference-in-difference, rural mountain context, up-scaling

JEL Classification Code:

D10; D14; D60; I30

\section{Citation:}

Ahmad, Tariq; Shah, Ghulam-Muhammad; Ahmad, Farid; Partap, Uma; Ahmad, Sajjad (2017); Impact of Apiculture on the Household Income of Rural Poor in Mountains of Chitral District in Pakistan; Journal of Social Sciences (COES\&RJ-JSS), Vol.6, No.3, pp:518-531; https://doi.org/10.25255/jss.2017.6.3.518.531.

This work is licensed under a Creative Commons Attribution 4.0 International License. 


\section{Introduction}

Apiculture is raising, management and maintenance of honeybee colonies for better economic and environmental benefits. It is defined as an art and science of rearing, breeding, managing, and maintaining honeybees for getting economic and environmental gains (Ezekiel et al., 2013; Nwali, 1996; Morse, 1989; Ikediobi et al., 1985).

In terms of potential economic contribution of beekeeping,(Gidey Y., Mekonen T, 2010) have suggested that beekeeping is an environmentally friendly and non-farm business activity that has immense contribution to the economies of the society and to a national economy as whole. Beekeeping generates product[s] with high market potential, while being more easily adapted to constraints of low credit and limited land access than other agricultural activities (Cristina B, Molly Mc, 2015). In this regard beekeeping could be considered as a reliable source of alternative income. (L.R., Verma, 1990)has argued that beekeeping can make a significantcontribution to the economic upliftment of small and marginal farmers in terms of food and cash income, and gainful employment near home. Beekeeping can help economically vulnerable communities achieve economic stability. Honey production, pollination services, agriculture, and forestry are but a few of the economic benefits of beekeeping (F. Ahmad et al, 2007). On similar lines (Famuyide O. et al, 2014) claimed that beekeeping has becoming popular among small scale farmers because farmers have resorted to making income in diverse ways. Honey production is undertaken because it provides both social, environmental,economic and health benefits to rural communities and has received primary attention from the farmers.

Rural poor dependent on subsistence agriculture and small farm lands often rely on alternative sources of income for their livelihoods. For such circumstances, (Yap, Devlin, 2015; Wolff et al., 2015) propose that beekeeping is often promoted in the context of rural development because the practice provides monetary, nutritional, and social benefits to poor families, without requiring land ownership or large amounts of capital investment.According to (Lietaer, 2007), beekeeping can be practiced as an additional source of income for farmers in rural areas and has been successfully implemented in poverty-alleviating projects. (Joni, 2004) also states that beekeeping plays a major role in the socio-economic development of rural livelihoods. (Mazorodze Brian T., 2015) suggests thatbeekeeping not only contributes to uplifting the livelihoods of rural communities but protects the trees and ultimately contributes to protecting our planet earth. He further argues that beekeeping is ecological friendly, requires few resources to start up production, can be quickly taken up again after a crisis period and the necessary skills are easily transmitted from one generation to the other making it a sustainable livelihood strategy. Arguing on resource requirement and investment in beekeeping endeavors, (Bradbear, 2009) also concluded that beekeeping does not require expensive equipment, as simple hives can be made from local materials by local artesian.

Multiple studies have shown that many countries have tapped greater economic as well as environmental potential of bee keeping (McKee, B., 2003;Cunningham, S.S. et al, 2002; Carol A. et al, 1998). This is particularly true in the case of developed countries where honeybee keeping and honey production is a lucrative enterprise (Staveley, J. P. et al, 2014; Jaffé R. et al, 2015; 2010).However, potential of beekeeping in developing countries is far too often not exploited in development programmes because the benefits of bees and beekeeping are not well known to stakeholders (Mazorodze Brian T., 2015). For example (Dietemann et al., 2009; Carroll, Kinsella, 2013) found that comparison to 
Europe, beekeeping in Africa is practiced as a supplemental income source to households. Here one could sensibly argue that development priorities in developed economies have gone beyond poverty alone consideration of development. Consequently, these economies are able to better invest in apiculture, bring apiculture to scientific footings and standardize apiculture practices, diversify honey products thereby reaping economic and environmental potentials of beekeeping to the fullest(Imperatriz-Fonseca, V. L., et al,. 2006). Developing economies on the other hand are not able to invest and capturefully the potential benefits of apiculture mainly because deteriorating poverty conditions driving development priorities.Nonetheless, in developing countries context beekeeping help reduce poverty. Among others one such example is from Nigeria where according to (Ayansola, 2012) beekeeping helps eradicate poverty especially in the rural communities.

From the above literature review it could be logically established that beekeeping has proven to be an alternative livelihood option with potential of providing income security to rural poor and smallholder farmers. Exploring these options in the unique context of Hindu Kush Himalayan (HKH) Mountains could be of specific interest to many researchers, evaluation professionals, development practitioners and development organizations.

Living conditionsof mountaincommunities is unique because ofthe physical characteristics of mountain regions which restrict access to larger livelihoods opportunities, hence development of mountain niche products such as mountain honey and other honey bee products becomes critical. In addition, distorted market conditions do not allow them to obtain the right price for their honey and other bee products (ICIMOD, 2008). Mountain populations are, on the whole, poorer than the national average in the HKH region (Hunzai, K., et al, 2011) and majority of population in the Hindu Kush-Himalayan region lives at or below, the subsistence level, and mainly in rural areas (L.R., Verma, 1990).The region is poor in basic infrastructure and services. Road connectivity and communication services are limited. The remoteness, inaccessibility and fragility of the Hindu Kush Himalayan region aggravate poverty. At the same time, the livelihoods and food security of mountain communities depend heavily on the local resource base at all elevations, although the specific agro-ecological and livelihood potentials vary considerably. Subsistence agriculture, livestock and horticulture are the main sources of livelihoods, with livestock becoming more important than arable farming at higher elevations. (Abid Hussain et al, 2016).

In the context of honeybee species diversity the Hindu Kush-Himalayan Region is one of the richest in the world. At least five different species of honeybee are found in this region (Uma Partap, 1997). According to (ICIMOD, 2008), the HKH region produces over 36 thousand metric tons of honey per year from over four million colonies and nests of indigenous and other honeybees. Yet most of the bee farmers of the HKH region fall into the category of the poorest of the poor. They live in inaccessible areas and manage their honeybees in their backyard gardens, producing small quantities of honey (ICIMOD, 2008). Broad rational development of apiculture in the Hindu Kush-Himalayan region offers varied possibilities, several advantages and great promise to a developing economy. Rough estimates show that modern beekeeping can contribute millions of dollars through sale of hive products and pollination services (L.R., Verma, 1990). The Khyber Pakhtunkhwa (KPK) province - where the study area is situated, is considered highly suitable for beekeeping for its diversified ecological zones containing rich bee flora and 
ideal climatic conditions for beekeeping. However the beekeepers have limited knowledge of modern beekeeping management practices (Rakesh Kumar Gupta et al., 2014). Mountain specificities discussed above equally pose challenges to beekeeping sector.

In this prospective, to what extent beekeeping contributes to and provides a reliable alternative income security to the rural poor and small holder farmers living in mountains could be of interest to many researchers, evaluation professionals, development practitioners and organizations. Beekeeping is usually a complementary farming activity with diverse socio-economic importance. While the value of beekeeping for household income is frequently mentioned, this is often done as a logical assumption rather than using empirical evidences (WorkuAbebaw, 2012). Although many researchers, for example, (Ajao and Oladimeji, 2012) assessed the contribution of apicultural practices to household income and poverty alleviation in Kwara state of Nigeria. Their study has found that the average net return per litre of honey produced range from ${ }^{1} 1200$ to 1500 while average income per season per colony ranges from $\$ 7500$ to $\$ 10000$. Similarly (Qaiser, Ali, Taj, Akmal, 2013) while assessing impact of beekeeping in sustainable rural livelihood in Chakwal and Sargodha districts in mainland Pakistan also found to increase beekeepers' income although this ratio found to be low in the study area. (Saha, 2002) in Bangladesh through an exploratory study concludes beekeeping as a profitable venture requiring small investment and skilled labor and high yield enterprise compared to other interventions aiming at poverty reduction.

This study is unique in the sense that it provides evidence based insights into the impacts of beekeeping in terms of the extent of contribution of beekeeping in increasing household income of beekeepers and provisioning of a reliable alternative livelihood option specifically in the unique context of rural smallholder farmers living in mountains of the HKH. This study is also unique because the study has been conducted in an ex-post scenario giving us some good insights into suitability and sustainability aspects of the intervention.Ex-post impact assessments provide reliable evidences of impact particularly in terms of relevance under changing environments, adoption and sustainability. For example, the meta-analysis of ex post impact assessments conducted by (Raitzer and Kelley, 2008) found that more than $90 \%$ of the benefits in the moderately inclusive scenario were generated by Centres of the Consultative Group on International Agricultural Research (CGAIR's) three research areas including cassava mealybug biocontrol and breeding of modern varieties of spring bread wheat and rice. Thus, attention to more ex post impact assessments were recommended for areas of CGAIR research for which there is less documented evidence of impact (Timothy Kelley et al., 2008). Despite challenges of confounding complementarity factors, lag time issues in changing environments, ex-post impact assessments as a summative form of evaluation appears to become more appropriate to strategic, long-term information needs (Timothy Kelley et al., 2008). Mostly evaluations are used for operational decision making. Depending on the nature of evaluation and interest of stakeholders, in some cases evaluations are used for strategic decision making. (MacKay and Horton, 2003) also recognizes that differenttypes of evaluation are more relevant to operationaldecision making than to strategic decision-makingwithin a given organization. As set of ex-post impact evaluations grow, a greater body of evidence will exist on which strategic lessons on what type of [interventions and] research is most effective from impacts perspective,

${ }^{1} \#=$ Nigerian naira 
when and under what type of conditions and for whom (Raitzer and Kelley, 2008) can be drawn for the systems (Timothy Kelley et al., 2008).

\section{Brief description of beekeeping pilot intervention}

Aiming at filling the knowledge gaps on the contribution of indigenous honeybees to household income and mountain livelihoods in the Himalayas, ICIMOD initiated a research programme on indigenous Honeybees of the Himalayas in 1991. Under his research ICIMOD promoted apiculture development in the HKH region and supported conservation of indigenous species 'Apiscerana' and wild Himalayan honeybees, studying their environment (flora and fauna) and the communities (F. Ahmad, et al., 2003). Over time, ICIMOD's intervention in beekeeping evolved from research to extension and ICIMOD initiated pilot interventions in the mountain and hilly areas of Bangladesh, Bhutan, India, Nepal and Pakistan. Intervention aimed at providing an alternative livelihood and income option to beneficiary households.As part of these pilot interventions ICIMOD intervened in selected areas in these countries. Beekeeping pilot interventions got momentum across these countries during 2009. ICIMOD introduced conservation and promotion of Apiscerana and other indigenous honeybees, as an alternative and reliable source of livelihood and alternative income security, built capacity of beekeepers on various aspects of beekeeping, i.e. management and maintenance of honeybee colonies, harvesting, processing, and managing honeybees for mountain crops pollination. Beneficiaries in these selected pilot intervention areas were provided tools and equipment required for raising, managing and maintaining bee colonies. Considering acceptance of the pilot interventions by smallholder farmers in these rural mountains and hills, ICIMOD provided capacity building support to local institutions in the pilot intervention areas in linking farmers to markets.As part of the capacity building, beekeepers and representatives of local institutions in the pilot intervention areas were provided exposure visits to select Regional Member Countries (RMCs). ICIMOD also arranged multiple dissemination and sharing of experiences and knowledge workshops for the beneficiaries.

ICIMOD implemented these pilots through partners inBangladesh, Bhutan, India, Nepal and Pakistan. ICIMOD partners included academic institutions, bee keepers' associations, government and non-government organizations (NGOs) and cooperatives involved in beekeeping development andgovernment units including its research facilities on beekeeping development. In Pakistan, the pilot intervention on beekeeping was implemented by the Aga Khan Rural Support Programme (AKRSP) in selected villages in Chitral district in KPK - then NWFP, province. Pilot interventions in these countries concluded during 2012.

\section{Description of study area}

ICIMOD's Pilot intervention area in Pakistan included District Chitral in KPK province. District Chitralis located at an altitude of 2500-12,000 feet. It is spread over an area of 14,850 square kilometers. Per capita income in Chitralis PKR 24,660. Overall more than $32 \%$ of the population is living below poverty line.Majorsource of income is the agriculture and livestock followed by off farm employment (AKRSP 2010). Beneficiary villages included Reshun, Koghuzi, Kuragh and Kailash. Pilot villages were selected based on the willingness of communities to participate in the intervention. 


\section{Empirical approach used for the study}

In this study we have applied a higher order difference estimation approach. Using 'difference-in-difference' or 'double difference' methods of higher order difference estimation, we have calculated impact estimate for income of the beneficiary households. The essential idea in 'difference-in-difference' estimator is to compare samples of participants and non-participants 'before' and 'after' the intervention. Beneficiary and non-beneficiary areas are declared and baseline is developed for both beneficiary and nonbeneficiary households at the beginning of the intervention. A follow-up survey of both groups is conducted after the intervention. Finally difference between 'after' and 'before' values of the average outcomes of interest for each of the beneficiary and non-beneficiary (also referred as treatment and comparison groups) is calculated and differencebetween mean differences of treatment and comparison group - the double difference, is considered as the impact estimate of the outcome of interest. (Howard White, ShagunSabarwal, 2014) suggest that 'difference-in-difference' gives a stronger impact estimate than single difference, which only compares the difference in outcomes between treatment and comparison groups following the intervention at time $(t+1)$. They argue that applying 'difference-in-difference' method removes the difference in the outcome between treatment and comparison groups at the baseline (Howard White, ShagunSabarwal, 2014). 'Difference-in-difference' estimation methods are widely used in impact assessment of socio-economic development interventions. For example, using district level data, (Binswanger, Khandker, Rosenzweig, 1993) used this method to estimate the impacts of rural infrastructure on agricultural productivity in India. Using 'difference-in-difference' (Galiani, Gertler, Schargrodsky, 2005) have studied the impact of privatizingwater services on child mortality in Argentina.In addition to 'difference-in-difference' approach, descriptive statistics and specific figures have been used to describe characteristics of households included in the study, women's involvement in beekeeping and decision making role regarding income.

Archetypally impact measures an intervention's performance on a defined observable outcome of interest against a relevant and explicit counterfactual. An observable outcome indicatorY is defined as relevant to the intervention and time period over which intended impact is expected. In this relation impact is the change inYthat can be causally attributed to the intervention. Data requires an observation for the Yifor each unitiin a study samplen. Treatment statusTiis observed in a way that $\mathrm{Ti}=1$ when unitiin the samplenis a beneficiary, that is treated, andTi $=0$ when it is not. (Ravallion, M., 2007)defines this as archetypal formulation of the evaluation problem. This postulates two potential outcomes for eachi, that is, the value of Yiunder treatment, $\mathrm{Yi}^{\mathrm{T}}$ and $\mathrm{Yi}^{\mathrm{C}}$ under counterfactual of not receiving treatment. Then UnitigainsGi $=\mathrm{Yi}^{\mathrm{T}}-\mathrm{Yi}^{\mathrm{C}}$. Whereas, Giis generally termed as causal effect of the intervention for unit $i$. In order understand what involves in a 'difference-in-difference' design, let us considerY $Y_{i t}$ denotes outcome measure fori ${ }^{\text {th }}$ observation units observed at time, $t=0,1$. By definitionYit $=\mathrm{Yit}^{\mathrm{C}}+$ TitGit, assumes that we can observe Titand ${ }^{2} t^{\mathrm{T}}$ wnenTit $=1$, Yit ${ }^{\mathrm{C}}$ forTit $=0$. However, Git $=\mathrm{Y}^{\mathrm{T}} \mathrm{i}$ it $\mathrm{Y}^{\mathrm{C}}$ iyis not directly observable for any ibecause $\mathrm{Y}^{\mathrm{T}}$ itfor Tit $=0$ and $\mathrm{Y}^{\mathrm{C}} \mathrm{it}=1$ is unobserved or missing. In this case, 'difference-in-difference' estimator assumes that the unobserved difference in mean counterfactual outcome between treatment and comparison units is time invariant. That is, outcome changes for comparison group reveal the counterfactual outcome changes which could be written as: $\mathrm{E}\left(\mathrm{Y}_{1}{ }^{\mathrm{C}} \mathrm{Y}_{0}{ }^{\mathrm{C}} \mid \mathrm{T} 1=1\right)=\mathrm{E}\left(\mathrm{Y}_{1}{ }^{\mathrm{C}}{ }^{-} \mathrm{Y}_{0}{ }^{\mathrm{C}} \mid \mathrm{T}_{1}=0\right)$ 
Since period 0 is baseline with $\mathrm{T}_{0} \mathrm{i}=0$ for alli, $\mathrm{Y}_{0} \mathrm{i}=\mathrm{Y}_{0 \mathrm{i}}^{\mathrm{C}}$ for alli, then 'difference-indifference' estimator gives the mean treatment effect on the treated for period 1.This could be written as:

Difference-in-difference $=\mathrm{E}\left(\mathrm{Y}_{1}{ }^{\mathrm{T}} \mathrm{Y}_{0}{ }^{\mathrm{C}} \mid \mathrm{T}_{1}=1\right)-\mathrm{E}\left(\mathrm{Y}_{1}{ }^{\mathrm{C}}-\mathrm{Y}_{0}{ }^{\mathrm{C}} \mid \mathrm{T}_{1}=0\right)=\mathrm{E}\left(\mathrm{G}_{1} \mid \mathrm{T}_{1}=1\right)$

\section{Material and methods}

Using mixed methods approach data was collected from a total of 160 households $(\mathrm{HH})$. This includes 80 beneficiary and 80 non-beneficiary HH. List of beneficiary households from four beneficiary villages were prepared through a listing survey of the beneficiary households. A total of and 80 households were selected randomly from an overall 101 households from four beneficiary villages. Similarly, all eligible non-beneficiary households $^{2}$ were listed from the same four villages and 80 eligible non-beneficiary households were randomly selected from a total of 118 eligible non-beneficiary households. A household survey questionnaire was used to collect data from these households. In addition, three Focus Group Discussions (FGDs) and threeKey Informant Interviews (KIIs) were conducted with selected stakeholders. As the study was conducted in ex-post scenario, Year 2009 was used as base year as the beekeeping pilot intervention got started during this year. The ex-post impact assessment was conducted in 2016. Household was taken as unit of analysis for the study. Baseline data was not available for the pilot intervention, therefore using recall method we reconstructed the baseline. Recall method has been used by multiple researchers in scenarios where baseline is not available. For example, (Deaton, Grosh, 2002;Belli, Stafford, Alwin, 2009) have concluded that when carefully designed and implemented, recall method can be a useful estimation tool. (Michael Bamberger, 2010) has also suggested recall method as potentially a valuable way to reconstruct baseline data under data constraints. Discussing relevance of recall method, (Deaton, Grosh, 2000) have further suggested that recall is used in poverty analysis, demography, and income expenditure surveys.

\section{Results}

'Difference-in-difference' analysis suggests that the average annual income from beekeeping of the beneficiary and non-beneficiary households during the base year, 2009, is $\mathrm{PKR}^{3}$ : 67,374.77 and PKR: 11,286.45 respectively. Whereas these estimates for the expost evaluation year, 2016, is found to be PKR: 10,2105.10 for beneficiary households and PKR: 11,341.14 for non-beneficiary households. Therefore, the causal impact of the intervention is found to be PKR: 34,730. This suggest that the average household income from beekeeping of the beneficiary households in the ex-post scenario is increased by $51.54 \%$ compared to the average income of beneficiary households assessed at the end of the pilot intervention. Table 1 below provides a summary of the estimates calculated using 'difference-in-difference' method of calculation.

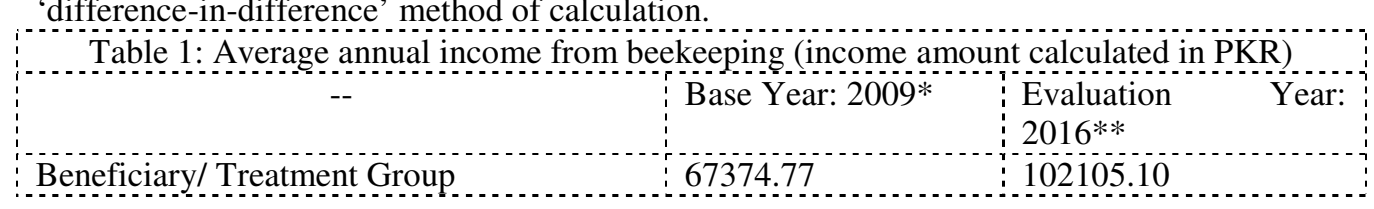

${ }^{2}$ Eligible non-beneficiary households are the one who live in the beneficiary villages and practice beekeeping by their own but who did not receive any inputs from ICIMOD's pilot intervention on beekeeping. Socioeconomic conditions of the beneficiary and non-

beneficiary villages are the same.

${ }^{3}$ PKR = Pakistani Rupee. One PKR = USD 108 


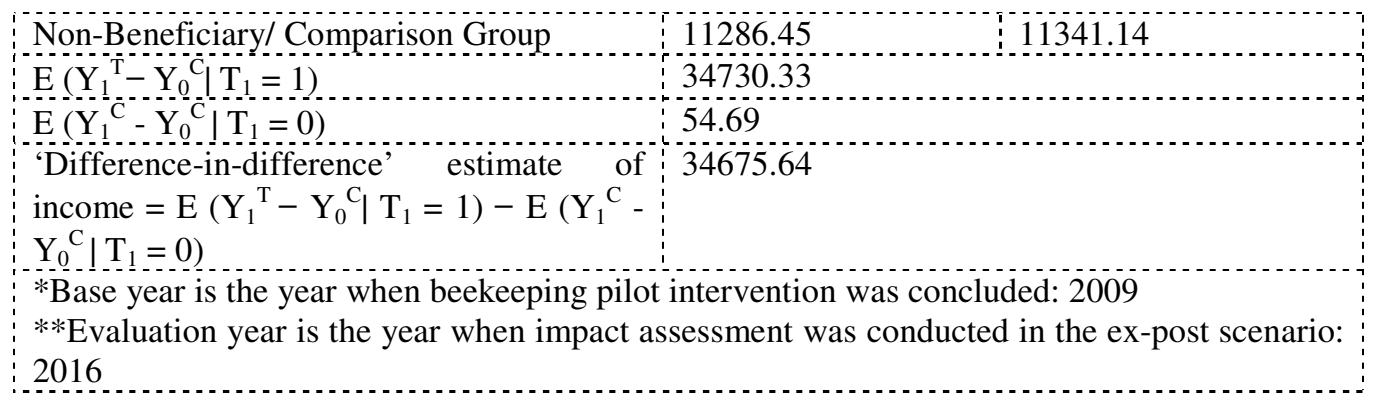

\section{Concentration of income values}

Yearly average income from beekeeping of households included in the study is mainly found to be clustered around PKR 0 to 300,000. Zero at the baseline and PKR. 300,000 over time assessed at ex-post period. We found few outlier households particularly in the beneficiary villages with average yearly household income from beekeeping more than a million also. Households who stood outliers are actually the one who become local level bee entrepreneurs selling beehives, tools and equipment involved in beekeeping. Figure 1 below shows concentration of income values for both beneficiary and comparison households. Income figures cover whole of the pilot intervention period.Study found variation in the concentration of income between beneficiary and comparison households. It is because of the exposure of beneficiaries to the intervention itself. We specifically looked into the density of income among the comparison households and we found that it lies at PKR. 50,000.The maximum income for the comparisongroup was found to be PKR. 200,000 in 2009which increased to PKR. 276,000 in 2016. Whereas it raised from PKR. 1 million in 2009 to 2.5 million in 2016 for the treatment group.

Figure 1: Concentration of income values for study group

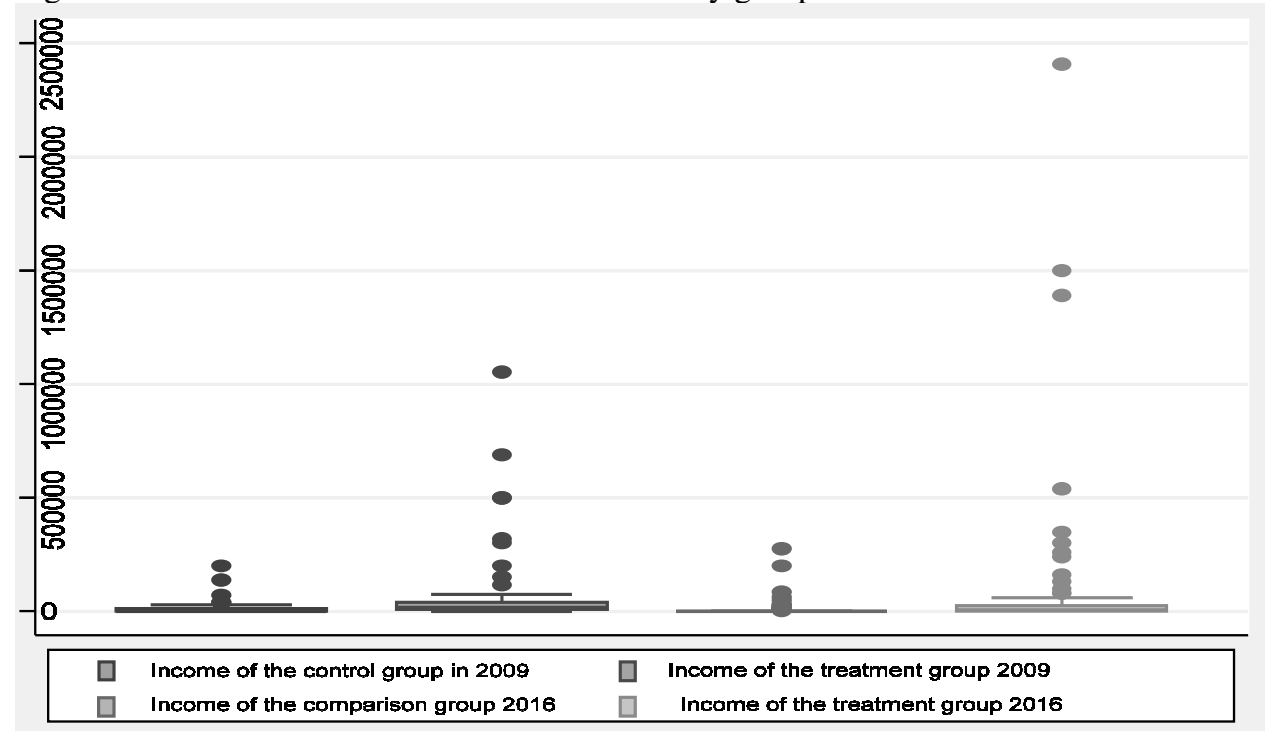

\section{Gender roles in beekeeping}

Study looked at gender roles in beekeeping from involvement of women and men and inclusiveness perspectives. In this regard, study looked into involvement of women and men in rearing bees, decision making role of women and men regarding beekeeping, and 
decision making role of women and men regarding use of income earned from beekeeping. Findings of the study suggests that among 80 households surveyed in the beneficiary villages, in $49 \%$ of the cases women are equally involved with their male counterparts in rearing bees whereas women involvement in beekeeping for the nonbeneficiary households remains at $37 \%$. In case of women-only looking after bees, it is less among the beneficiary households compared to non-beneficiary households. This is because beneficiary households usually have more beehives thus looked after by both female and male counterparts. In terms of gender roles of decision making regarding keeping of honeybees, findings of the study suggest that $53 \%$ of women in beneficiary households and $30 \%$ of women in non-beneficiary households take such decisions. We tried to understand this aspect further during FGDs and we found that since women in this region are more involved in household level decisions and since beekeeping provides women at the household level option to earn an independent income, therefore women are seen almost equally involved in beekeeping. Figure 2 below presents the overall scenario of gender and inclusion at household level in terms of decision making on keeping bees, participation on beekeeping, and use of income earned from beekeeping.

Figure 2: Gender roles in beekeeping

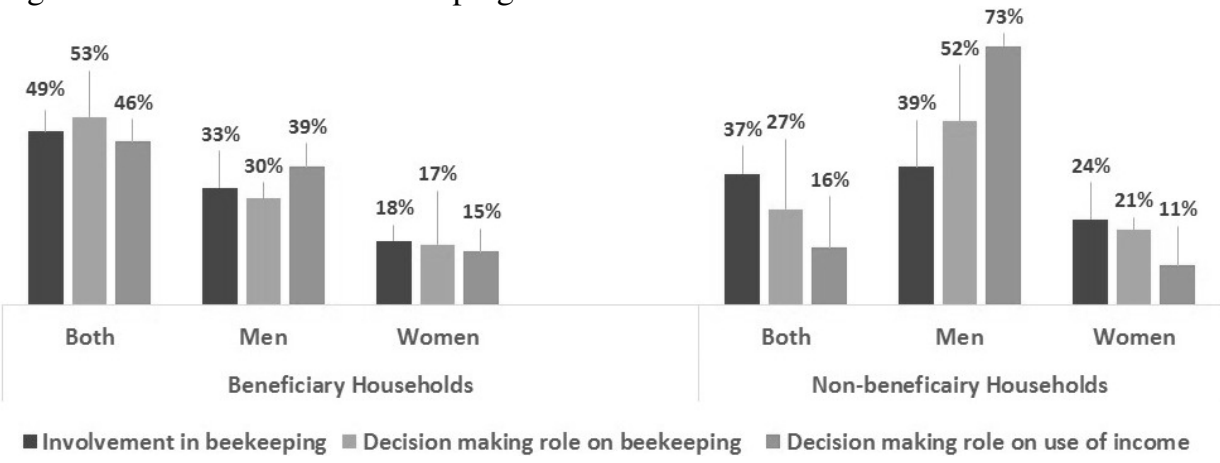

In terms of decision making on the use of income earned from beekeeping at household level, $46 \%$ of the total respondent beneficiary households suggests that women are involved in joint decision making on use of income at household level earned from beekeeping. This remains at 16 percent for the non-beneficiary households. Among nonbeneficiary households $73 \%$ of men are found to be sole decision makers on the use of income earned from beekeeping. Whereas this figure is $39 \%$ for the beneficiary households. Analysis of the gender role suggests that pilot intervention on beekeeping is positively impacting women in terms of their involvement in beekeeping and decision making role at household level.

\section{Up-scaling of beekeeping as an alternative livelihood option}

The FGDs and KIIs conducted during the study revealed that beekeeping is being practiced by a wider community in the district across many villages. Community based local organizations including NGOs support up-scaling of beekeeping activities across the district. This suggests that capacity building of community based local organizations by ICIMOD's pilot intervention on beekeeping is also bearing fruit in terms of supporting wider community for improving their alternative livelihoods. However, study was limited to direct beneficiaries and a limited number of non-beneficiary households - for comparison purpose, in the surrounding villages who voluntarily took-up beekeeping. 
Therefore we could not capture wider aspects of impacts through up-scaling of beekeeping intervention by the wider community.

\section{Use of income earned from beekeeping}

Livelihood of communities living in mountain areas is typically dependent on subsistence agriculture and smallholder farming. Rural mountain communities generally require an additional source of income, especially cash income, to meet their routine livelihoods requirements. Findings of the study suggest that beekeeping is proven to be such an alternative livelihood option which provides an alternative income security to smallholder farmers living in rural mountain areas of Chitral. Findings of the study illustrate that both beneficiary and non-beneficiary households included in the study were able to use income earned from beekeeping for household benefits. Around $33 \%$ of the households included in the study spent up to $25 \%$ of the income earned from beekeeping for better schooling of their children. Findings further reveal that more than $10 \%$ of the income earned from beekeeping by majority of the households included in the study spent on health aspects of their households. Majority of the respondents reported that they are able to timely see a doctor as they are able to use earnings from beekeeping and afford the transportation to health centers, doctor's consultation fee and medicine. A considerable number of beneficiary households found reinvesting earnings from beekeeping to buy modern beekeeping technologies so that they could further strengthen their beekeeping venture. Rural mountain communities are often socially highly connected. Data collected during FGDs suggest that beekeeping has enabled both beneficiary and non-beneficiary households raise their social status in the society because they are able to donate earnings from beekeeping to community schools and other social events. Besides, both beneficiary and non-beneficiary households are using honey produced at their home beehives as gifts to friends and relatives. Analysis of honey being consumed at home and for gifts suggests that average annual consumption of honey at homes by both beneficiary and nonbeneficiary households is 6 kilogram $(\mathrm{kg})$ per household whereas on average each household gifts $5 \mathrm{~kg}$ to their friends and relatives.

\section{Conclusion}

ICIMOD's pilot intervention on beekeeping has a positive impact on the income of beneficiary households in rural mountain areas of Chitral district in Pakistan. Intervention has gone beyond beneficiary villages as beekeeping has been up-scaled across Chitral district through local institutions. This suggests that even in the rural mountain context where communities are typically dependent on subsistence agriculture on small patches of their agriculture land, beekeeping is providing an alternative livelihood option and a reliable alternative income security to smallholder farmers. In terms of sustainability of beekeeping as an alternative and reliable source of livelihoods and income in the context of rural mountains, study finds that even in the ex-post scenario more than $80 \%$ of the beneficiary households' still practice beekeeping and earn an alternate income in the absence of any external support. The FGDs revealed that among the beneficiaries who abandoned beekeeping is because their beehives were attacked by some disease or pests when the households were in the pasture lands up in the mountains with their goats, they could not look after beekeeping. Following factors particularly contributed to the sustainability of the intervention:

i. Intervention was research based and relevant to the needs and overall environment of the rural mountain community; 
ii. Livelihood of communities in rural mountains is mainly dependent on subsistence agriculture; they always require an alternative source of income. Communities see beekeeping as a good alternative;

iii. Beekeeping is manageable besides an engaging primary occupation. It does not require land to be owned by the beekeepers as they keep their honey bee colonies on the margins of the land they own and on the communal land in the peripheries of the local area; and,

iv. Ownership of the intervention by the community and local organizations.

\section{Discussion and way forward}

Given the relevance of beekeeping as an alternative and reliable livelihood option in rural mountain context and given positive impacts of beekeeping on household income of rural mountain smallholders, it is suggested that:

i. An intervention at scale should be taken to rural mountain communities specifically concentrating on beekeeping value chain development involving connecting beekeepers to district level as well as to national level markets. Study found that more that $59 \%$ of the beekeepers both in beneficiary and non-beneficiary areas sell honey to traders visiting these villages from outside. Around $32 \%$ of honey producers in these villages sell their honey produce in the local market, that is, to a shopkeeper in their villages. In both cases beekeepers do not get a fair price for their produce. Eventually local traders buy honey on cheaper price from local honey producers and sell it on marginal price in the district level market and beyond. Only $9 \%$ of the honey producers sell their produce in the district level market. Beekeepers sell their produce individually. In this scenario, honeybee value chain development will not only add value in terms of improved quality of honey produce but also benefit rural mountain beekeepers in getting a fair price for their produce. On the other hand, beekeeping value chain development at scale will also meet larger demand for mountain honey in the national market;

ii. Currently, around $96 \%$ of both beneficiary and non-beneficiary beekeepers sell their honey producewithout proper branding and packaging. Study found that beekeepers do not have much idea of the importance of proper branding and marketing. Only $4 \%$ of beekeepers do packaging locally under a specific name. However their packaging practices are at individual level without following any packaging or branding standards. Therefore, it is highly recommended that a collective branding and packaging approach is included in the overall value chain development; and,

iii. Capacity of local beekeepers, honey entrepreneurs, and local institutions on how to manage business and how to market product is strengthened so that beekeeping is further strengthened as an alternative livelihood option for wider rural mountain communities and beekeeping becomes a reliable and sustainable income resource for the rural mountain communities. This will further help developing an entrepreneurial culture among local beekeepers, honey entrepreneurs and foster business capacities in order to manage horticulture as a business independently by individuals and groups.

\section{Acknowledgement}

We would like to acknowledge valuable contribution of AKRSP, Regional Office Chitral during fieldwork for this study. The authors also acknowledge respondents of the household survey, KIIs and FGDs. Thanks also to Himalayan Adaptation, Water and Resilience (HI-AWARE) Initiative for providing author(s) with the opportunity to attend training of impact evaluations. The authors gratefully acknowledge the support of core donors of ICIMOD: the Governments of Afghanistan, Australia, Austria, Bangladesh, Bhutan, China, India, Myanmar, Nepal, Norway, Pakistan, Switzerland, and the United 
Kingdom. The views and interpretations expressed in this publication are those of the authors and are not necessarily attributable to ICIMOD or any other organization.

\section{References}

Ajao, A.M. and Oladimeji, Y. U. (2013).Assessment of Contribution of Apicultural Practices to Household Income and Poverty Alleviation in Kwara State, Nigeria, International journal of science and nature, 4 (4) 2013: pp 687-698.

AKRSP, (2010). An assessment of socio economic trends in Northern areas and Chitral.

Ayansola, A.A, (2012). An Appraisal of Apicultural Practices in Southwestern Nigeria, Journal Agricultural Science, 3(2), pp 79-84.

Belli, F., F. Stafford, and D. Alwin.(2009). Calendarand Time Diary Methods in Life Course Research.Thousand Oaks, CA: Sage Publications.

Binswanger, H., Khandker, S.R., Rosenzweig,M. (1993). How infrastructure and financial institutions affect agricultural output and investment in India". Journal of Develop Economics, 41, pp 337-366.

Bradbear, N. (2009). Bees and their Role in Forest Livelihoods. Food and Agriculture Organization of the United Nations.

Carol A. Kearns, David W. Inouye, and Nickolas M. Waser, (1998). Endangered Mutualism, the Conservation of Plant-Pollinations, Annual Review of Ecology and Systematics, 29, pp 83-112

Carroll, T., \& Kinsella, J. (2013). Livelihood improvement and smallholder beekeeping in Kenya: the unrealised potential. Development in Practice, 23(3), pp 332-345.

Cristina Bianca Pocol, Molly Mc Donough. (2015). Women, Apiculture and Development: Evaluating the Impact of a Beekeeping Project on Rural Women's Livelihoods. Bulletin UASVM Horticulture 72(2).

Cunningham, S. A., FitzGibbon, F., \& Heard, T. A. (2002). The future of pollinators for Australian agriculture. Crop and Pasture Science, 53(8), pp 893-900.

Deaton, A., and M. Grosh. (2000). “Consumption.”In Designing Household Survey Questionnaires for Developing Countries: Lessons from 15 Years of the Living Standards Measurement Study, Vol. 3, ed. M. Grosh and P. Glewwe, 91-134. Washington, DC: World Bank.

Dietemann, V., Pirk, C. W. W., \& Crewe, R. (2009). Is there a need for conservation of honeybees in Africa? Apidologie, 40(3), pp 285-295.

Ezekiel, A.A, Olagunju, F.I and Olapade-Ogunwole, F. (2013). Economics of Honey Production in Oyo State, Nigeria. Global Advanced Research Journal of Arts and Humanities (GARJAH), 2(2) pp. 43-47.

F. Ahmad, Surendra R Joshi, Min B. Gurung., (2003). The Himalayan cliff bee ApisLaboriosa and the honey hunters of Kaski. Indigenous Honeybee of the Himalayas Vol (1), ICIMOD, Kathmandu, Nepal. Retrieved from http://lib.icimod.org/record/21832/files/attachment_124.pdf. Accessed May 4, 2017.

Famuyide, O.O., Adebayo, O., et al, (2014). Economic Contributions of Honey Production as a Means of Livelihood Strategy in Oyo State, International Journal of Science and Technology, 3 (1)?

F. Ahmad, Surendra R. Joshi, Min B. Gurung, (2007). Beekeeping and Rural Development. International Centre for Integrated Mountain Development.

Galiani, S., Gertler, P., Schargrodsky, E., (2005). Water for life: The impact of the privatization of water services on child mortality". Journal of Political Economy 113 (1), pp 83-119. 
Gidey Y and Mekonen T. (2010). Participatory Technology and Constraints Assessment to Improve the Livelihood of Beekeepers in Tigray Region, northern Ethiopia, Middle East Journal of Science, 2 (1), pp 76-92

Gupta RK, Reybroeck W, van Veen JW, Gupta A. (2014). Beekeeping for Poverty Alleviation and Livelihood Security?

White, H., \& S. Sabarwal. (2014). Quasi-experimental Design and Methods, Methodological Briefs. Impact Evaluation 8, UNICEF Office of Research, Florence. Retrieved from https://www.unicef-irc.org/publications/pdf/brief_8_quasiexperimental\%20design_eng.pdf

Hunzai, K., Gerlitz, J. Y., \&Hoermann, B. (2011). Understanding mountain poverty in the Hindu Kush-Himalayas: regional report for Afghanistan, Bangladesh, Bhutan, China, India, Myanmar, Nepal, and Pakistan. Kathmandu, International Centre for Integrated Mountain Development. http://lib.icimod.org/record/9376. Accessed at, on May 3, 2017.

Hussain, A., Rasul, G., Mahapatra, B., \& Tuladhar, S. (2016). Household food security in the face of climate change in the Hindu-Kush Himalayan region. Food Security, 8(5), 921-937.

ICIMOD (2008). Sustainable Mountain Development - ICIMOD Newsletter No. 54, Spring 2008 pages 26-30 "Living with honeybees - a decade of enrichment of thought and understanding" contributed by Farooq Ahmad and Uma Partap.

Ikediobi C. O., Obi V. C., Achoba I. A. (1985). Beekeeping and honey production in Nigeria. Nigerian Field 50: 59 - 70.

Imperatriz-Fonseca, V. L., Saraiva, A. M., \& De Jong, D. (2006).Bees as pollinators in Brazil. In Workshop on São Paulo Declaration on Pollinators plus 5 Forum (2003: São Paulo, Brazil). HolosEditora.

Jaffé R, Dietemann V, Allsopp MH, Costa C, et al. (2010).Estimating the density of honeybee colonies across their natural range to fill the gap in pollinator decline censuses, Conservation Biology, 24(2): pp 583-93.

Jaffé R, Pope N, Carvalho A.T, Maia UM, Blochtein B, et al. (2015).Bees for Development: Brazilian Survey Reveals How to Optimize Stingless Beekeeping, PLoS ONE 10(3). Also available at. https://doi.org/10.1371/journal.pone.0121157.

Joni, V. (2004).The Possibilities and Constraints of Improving Livelihoods through Apicultural Development in Ranomafana National Park in Madagascar, University of Helsinki.

Lietaer, C., (2007).Impact of beekeeping on forest conservation, preservation of forest ecosystems and poverty reduction.

MacKay, R and D Horton. (2003). Expanding the use of impact assessment and evaluation in agricultural research and development. Agricultural Systems, 78(2), 143165.

Mazorodze Brian T., (2015). The contribution of apiculture towards rural income in Honde valley, Zimbabwe. Presented at the National Capacity Building Strategy for Sustainable Development and Poverty Alleviation Conference, May 26-28, 2015, American University in the Emirates, Dubai.

McKee, B. (2003). Prevention of residues in honey: A future perspective. Apiacta, 38, 173-177

Meixner, M. D. (2010). A historical review of managed honey bee populations in Europe and the United States and the factors that may affect them. Journal of invertebrate pathology, 103, S80-S95. 
Michael Bamberger. (2010). Reconstructing Baseline Data for Impact Evaluation and Results Measurement. Special series on the nuts and bolts of M\&E system. Washington DC: The World Bank. from http://siteresources.worldbank.org/INTPOVERTY/Resources/3356421276521901256/premnoteME4.pdf. Accessed April 7, 2017.

Morse, R.A. (1989).History of Subsection; Apiculture and Social insects. Bulletin Entomology Society, America, 35, pp116-118.

Nwali, L. (1996). Agriculture Panorama. Media Extension, NAERLS, Ahmadu Bello.

Qaiser, T., Ali, M., Taj, S., and Akmal, N. (2013).Impact Assessment of Beekeeping in Sustainable Rural Livelihood. Journal of Social Sciences, COES\&RJ-JSS.

Raitzer D and T Kelley. (2008). Benefit-cost meta-analysis of investment in the International Agricultural Research Centers of the CGIAR. Agricultural Systems, 96, pp $108-123$.

Rakesh Kumar Gupta, WimReybroeck, Johan W. et al, (2014). Beekeeping for Poverty Alleviation and Livelihood Security. Springer Dordrecht Heidelberg New York London. DOI 10.1007/978-94-017-9199-1.

Ravallion, M. (2007). Evaluating anti-poverty programs. Handbook of development economics, 4, pp 3787-3846.

Saha, C, J. (2002).Beekeeping for Rural Development, Its Potentiality and Beekeeping against Poverty -Bangladesh Perspective, Standing Commission of Beekeeping for Rural Development.

Staveley, J. P., Law, S. A., Fairbrother, A., \&Menzie, C. A. (2014). A Causal Analysis of Observed Declines in Managed Honey Bees (Apismellifera). Human and Ecological Risk Assessment, 20(2), pp 566-591.

Timothy Kelley, Jim Ryan and Hans Gregersen. (2008). Enhancing ex post impact assessment of agricultural research: the CGIAR experience Research Evaluation, 17(3), pp 201-212.

Uma Partap., (1997). Bee flora of the Hindukush Himalayas: ICIMOD, Kathmandu, Nepal. Available accessed on May 3, 2017. Available at, http://lib.icimod.org/record/21940/files/Bee\%20Flora\%20of\%20the\%20Hindu\%20KushHimalayas-Low.pdf.

Verma, L.R. (1990). Beekeeping in Integrated Mountain Development: Economic and Scientific Perspectives. Oxford and IBH, New Delhi. Available at http://lib.icimod.org/record/25732/files/c_attachment_468_3721. Accessed May 19, 2017. WorkuAbebawAsressie, (2012). Bees for Development Journal 95.

Yap NT, Devlin JF., (2015). Beekeeping innovation for sustaining rural livelihoods. A success story. Innovation and Sustainable Development, 9(2), pp 103-117. 